\title{
An Examination of The Carsales.com.au's Business Model and Its Sustainability
}

\author{
John B. Hammond \\ Email:jhammond@netspace.net.au
}

\begin{abstract}
Business models have changed with the advent of the Internet and this has become more evident in retail business. Traditional way of sales have made way for new innovative business models involving online retail marketplace which has been coined e-marketspaces. Carsales.com.au had seen an opportunity to trade motor vehicles via an e-marketspace. The model was so successful that the company launched affiliated sites for trucks, caravans and bikes. This article outlines such models and compares with other familiar sites, and explores whether this model is sustainable.
\end{abstract}

Keywords: Carsales.com.au, e-marketspaces, business models, revenue models, motor vehicle industry.

\section{Introduction}

People have been buying cars ever since they rolled off the production lines. However, despite the fact that there are many more competitors in the motor vehicle industry producing more makes and models, very little has changed in the way cars were bought and sold until recent times.

In the past, there were only a few channels to buy or sell a car. These were either through a dealer (for new cars) or by a trader (either a second hand trader in business or by an independent private trader). The predominant medium was the newspaper and car magazines.

\section{The changing nature of the motor vehicle industry}

Ford was the first of the big manufacturing plants to set up in Australia in Geelong, Victoria in 1925. ${ }^{1}$ Holden followed at Port Melbourne a few years later. $^{2}$ Successive Australian Governments have fostered the home industry since these times by imposing tariffs on imported vehicles. Local industry flourished by the proliferation of companies producing components for the car industry.
The 1980s saw an intended rationalisation of the Australian motor vehicle industry and the transition to lower levels of protection i.e. tariff reduction. ${ }^{3+4}$ From the late 1980s, Australia has seen the erosion of the dominance of Ford and Holden giving way to imported cars from Japan and Korea.

The global financial crisis of 2008 coupled with increasing price of petrol has seen a large downturn in the motor vehicle industry worldwide. Inevitably motor vehicles manufactured locally will no longer be part of the Australian economy. From 2016, there will be no locally manufactured Ford vehicles ${ }^{5}$ and, the last of the Holden brand vehicles will roll off the production line in $2022{ }^{6}$

Using managerial tools is a good way to assess what is happening in an industry. Porter's five forces model is widely used to assess competitiveness. ${ }^{7}$

In 2012, there is still rivalry within the motor vehicle industry in Australia. Some of this rivalry is the dichotomy between the local and imported vehicles. However there is also rivalry within the local manufacturers. The annual race at Mount Panorama, Bathurst, NSW is testimony to the rivalry between Holden Monaro and Holden Commodore versus the Ford Falcon. This rivalry also extends to the drivers Peter Brock (driving for Holden) and Alan Moffat 
(driving for Ford) in the 1970s and the current stable of drivers for each manufacturer.

There are great barriers to entry due to the enormous capital cost to set up the manufacturing plant and to secure specialist manufacturers for the many components required. Many existing supply chains have been in place for long periods. For a new entrant, this poses an even greater barrier given the additional effects of the credit crisis on business. The Australian Government has taken away the import duties originally imposed to protect Australian manufacturers; therefore there is minimal additional cost for a branded vehicle imported by a branded manufacturer in Australia.

Buyers of new cars have far greater choice with more imported motor vehicles. No switching costs are present as a new car dealer will accept any make or model as a trade-in.

Suppliers have some limited power as they also compete with substitute products in the form of the different types of vehicles available (e.g., the conventional family vehicle versus the sports utility vehicle (SUV) as well as other modes - motor bikes, and motor-homes).

\section{The future of the Australian motor vehicle industry}

As noted above, due to a deliberate government decision in the 1980 s to reduce and ultimately remove tariff protection for the local manufacturing industry, the industry is in decline mode. With the announced closures of Ford plants by 2016, and Holden plants by 2022, many other companies who supply goods to the industry will also disappear. The market will be serviced by manufacturers located off-shore. For example a badged Japanese Toyota may be manufactured in China and imported into Australia.

With the impending demise of the local industry, will there be other changes in the industry that services its distribution?

\section{The changing distribution channels}

Historically when one was looking for a new car, one would have visited the showroom of a brander motor vehicle dealer. The dealer stocked the latest models as well as a few models from the previous year. Prospective purchasers were permitted to 'test drive' the one vehicle or many other models to 'get the feel of the car.'
Within the next 10 years, there will be no locally manufactured Ford or Holden vehicles. Will this also signal the demise of the franchised dealership selling Ford or Holden new vehicles? Maybe but maybe not!

Ford and Holden badged vehicles will still be manufactured around the globe and imported into Australia. The current franchises are the likely importers of these vehicles and will therefore continue to maintain the rivalry between what Australians would consider Ford versus Holden iconic vehicles. There will be allegiances to one of these brands by some diehard Australians.

Imported vehicles could be sold through partnership alliances similar to the airlines. In 1999, American Airlines, British Airways, Cathay Pacific, Canadian Airlines, and Qantas founded the global airline alliance OneWorld. ${ }^{8}$ Qantas have partnered with Singapore Airlines and Emirates in recent time. ${ }^{9}$ Could a similar business model extend to new vehicle dealerships?

\section{Factors that may impact on distribution}

As mentioned above, there will be no locally manufactured new vehicles after about 2022. There are many factors to consider in determining the distribution channel of the future. As suggested, there may be alliances developed between dealerships with a dichotomy of vehicles, namely Ford versus Holden similar to the dichotomy in airlines namely the Qantas group versus the Virgin Airlines and other airlines.

Will there be another political intervention to rationalise the motor vehicle distribution industry in the future? It is difficult to predict however governments are looking at less regulation rather than more regulation.

The economic crisis that has gripped the world since 2007/2008 has had an ongoing dampening effect in nearly every industry. The major car manufacturers in America sought and were granted massive financial assistance from Congress in 2009 which averted bankruptcy. ${ }^{10}$ Australian Holden also received government assistance in 2012/2013 to sustain the industry longer in Australia. ${ }^{11}$

Whilst there has been a move towards smaller fueleconomy vehicles in the past 20 years, there has also been an increase in fuel-hungry sports utility vehicles (SUVs) and other 4-wheel drive off-road vehicles. Meanwhile with technological advancements, the production of electric cars and hybrid vehicles has become a reality. This is intended to reduce the 
dependency on oil to run motor vehicles. Technology has also improved the emission of carbon - another 'greener' innovation in response to a carbon tax imposed on polluters. Australians have embraced concern for the environment however this does not always translate to their choice in motor vehicles.

Technology is also changing the way we work. Far more than at any time in the past, we have seen workers use their residence as their workplace. The Internet along with video-conferencing has brought the workplace to the residence for some workers. This has reduced the reliance on the motor vehicle as a means of transport to and from work.

Furthermore, with slowing population growth, the growth of sales of motor vehicles will also slow down.

So will there still be franchises as we currently know them?

\section{New distribution channels}

Similarly in the Internet permitting some workers to work from home, the internet has also changed the retail industry.

Many businesses which used to have a 'bricks and mortar' presence are now combining this physical location with a virtual sales site on the internet. Some businesses see this as simply a normal progression to reach more customers. These businesses do not see this as a new business model.

Carsales.com.au commenced as an online automotive classified business in $1996 .^{12}$ Being the first mover in this industry, it has claimed the top position in sales transactions for many years since. The website not only is a trading market for cars but includes boats, trucks, bikes, caravans, homes, machinery, equipment and related accessories.

Carsales.com.au has a simple but effective revenue model. The website charges each seller of say a motor vehicle a fee to list the vehicle until sold. The website also charges for advertising space. In recent times, it has offered data and information to dealers for a fee.

The online advertising offerings of carsales.com.au are divided into two categories namely classified advertising and display advertising. Classified advertising is the major revenue source predominantly from dealer customers and private sellers. For example, a seller (either dealer or private seller) places an advertisement for a specific vehicle for a price. This classified advertisement appears on the carsales.com.au online website. Display advertising typically involves corporate customers such as automotive manufacturers, importers, financiers, and insurance companies. These display advertisements appear for a specific time for a specific fee. Typically these advertisements include new vehicle promotional deals.

Revenue generated from both forms of advertising for the year ended 30 June 2013 was A $\$ 187,206,000$ of the total revenue of $\mathrm{A} \$ 216,461,000$ or just over $86 \%{ }^{12}$ This percentage has been constant over the past few years.

\section{The new Marketplace}

Carsales.com.au is a broker which provides a platform for connecting buyers and sellers. Each item offered for sale is offered by the individual owner or dealer who has placed the classified advertisement.

The model used by carsales.com.au is not new. eBay.com was launched in $1995^{13}$ in the same year as Amazon.com. ${ }^{14}$ eBay.com is an online auction and shopping website in which people and businesses buy and sell a broad variety of goods and services worldwide. The model has been expanded to include 'buy-it-now' or traditional shopping, and advertising space on the website.

Amazon.com commenced selling books and employed a different business model in that it actually sold the books it had purchased - thus it is an online retailer which used the internet as its trading space. In contrast, carsales.com.au does not own any vehicles which appear on their website. In addition to eBay.com, Amazon.com and carsales.com.au, there are many other similar marketspace companies including alibaba.com which is the largest in China. ${ }^{15}$

In the case of carsales.com.au, a seller incurs a oneoff fee to place the advertisement for the item until it is sold. The purchaser may offer a price lower than the advertised price. Initially the fee was only \$10 however over time this has risen to $\$ 60$. Carsales.com.au would need to monitor this pricing strategy carefully. Even though sellers have been willing to pay this fee based on sale success rates, there may be an upper limit before the sellers switch to another similar site.

Despite modest fees charged in relation to the price of motor vehicles, carsales.com.au is profitable with total revenue from operations of A $\$ 215,118,000$. Table 1 presents revenue sources of carsales.com.au. 
John B. Hammond

\begin{tabular}{|c|c|c|c|c|}
\hline \multirow{2}{*}{$\begin{array}{l}\text { Table 1. Revenue by Segment. } \\
\text { Sale of classified advertisements to dealers }\end{array}$} & \multicolumn{2}{|c|}{$A^{\prime} \$^{\prime 000}$} & \multicolumn{2}{|c|}{$\mathrm{A}^{\prime} 000$} \\
\hline & 84,243 & $45 \%$ & 71,883 & $45 \%$ \\
\hline Sale of display or banner advertising & 46,801 & $25 \%$ & 38,337 & $24 \%$ \\
\hline Sale of classified advertisements to private advertisers & 31,825 & $17 \%$ & 28,753 & $18 \%$ \\
\hline Provision of data and information technology services to dealers & 24,337 & $13 \%$ & 20,766 & $13 \%$ \\
\hline Segment revenue & 187,206 & $100 \%$ & 159,739 & $100 \%$ \\
\hline Information technology services & 27,912 & & 24,467 & \\
\hline Total revenue from operations & 215,118 & & 184,206 & \\
\hline Interest received & 1,343 & & 1,322 & \\
\hline TOTAL REVENUE & 216,461 & & 185,528 & \\
\hline
\end{tabular}

[Source: Carsales.com.au Annual Report 2013 ${ }^{12}$ ]

It can be seen from Table 1 that only a small percentage of the revenue from operations is derived from classified advertisements placed by private advertisers. Conversely it is seen from Table 1 that there is heavy reliance on the revenue stream from dealers from the sale of classified advertisements, sale of display or banner advertising and from the provision of information technology services. In fact, the 2013 revenue derived from dealers from these combined transactions amount to A\$155,381,000 (an increase of A\$24,395,000 from 2012).
To date, the trading exchange conducted by carsales.com.au has been very efficient. The efficiency has contributed to carsales.com.au not only being profitable, but also becoming the leading online automotive classified lister. Furthermore, being an early entrant has assisted carsales.com.au to become a recognized brand. It can be seen from Table 2 that carsales.com.au commands $38 \%$ of the market.

Table 2. Listings counted on each website on a day in August 2012.

\begin{tabular}{|l|c|c|c|c|c|c|}
\hline & \multicolumn{2}{|c|}{ Private } & \multicolumn{2}{c|}{ Dealer } & \multicolumn{2}{c|}{ Total } \\
\hline & Listings & Share & Listings & Share & Listings & Share \\
\hline Carsales & 73,550 & $40 \%$ & 149,349 & $37 \%$ & 222,899 & $38 \%$ \\
\hline Trading Post & 13,323 & $7 \%$ & 48,524 & $12 \%$ & 81,547 & $11 \%$ \\
\hline Carsguide & 28,117 & $15 \%$ & 123,220 & $31 \%$ & 151,337 & $26 \%$ \\
\hline Drive & 3,735 & $2 \%$ & 58,803 & $15 \%$ & 62,538 & $11 \%$ \\
\hline Gumtree & 61,541 & $33 \%$ & 8,571 & $2 \%$ & 70,112 & $12 \%$ \\
\hline eBay & 6,143 & $3 \%$ & 11,051 & $3 \%$ & 17,194 & $3 \%$ \\
\hline Total & 186,409 & $100 \%$ & 399,518 & $100 \%$ & 585,927 & $100 \%$ \\
\hline
\end{tabular}

[Source: ACCC report on carsales.com.au ${ }^{16}$ ]

Furthermore from Table 2, it can be seen that the volume of listings from dealers is more than twice the number of listings by private individuals with the exception of Gumtree. The reason why private listings outweigh dealer listings for Gumtree is that this site offers lower fees as well as free advertising for low cost items.
The business model of carsales.com.au is an Internet marketplace or commonly termed an e-marketplace or a marketspace. The trading place is the Internet although there is a degree of physicality in that the car (or other traded goods) are still physically delivered to or picked up by the buyer. In some instances, a third party 
delivery company may be involved as agreed by the buyer and seller.

A marketspace has three objectives:

(a) Matching buyers and sellers,

(b) Facilitating exchange of information, goods, services and payments,

(c) Providing institutional infrastructure enabling efficient functioning of the market. ${ }^{17}$

\section{A universal business model}

There are two components of a business model. These are a revenue model and a value proposition.

Depending on the particular site, the revenue model may be one or any combination of the following revenue streams:

(a) sales revenue from selling own goods and/or services,

(b) transaction fees based on the transaction value or per transaction,

(c) subscription fees,

(d) block advertising fees, banner fees, and other forms of advertising space,

(e) pay per view fees, pay per click fees, and

(f) affiliation or agent fees for referrals from other sites. $^{18+19}$

Value proposition is value created for customers and users or players in the marketspace which in the case of carsales.com.au would be the sellers.

Carsales.com.au creates value for its customers. Apart from the site being available to any buyer and any seller, the site offers customers (both individuals and businesses who place the advertisements) a useful and user-friendly online platform with appropriate search engine capabilities. In addition, the site offers a research option which provides detailed specifications and features for almost any car available in Australia. The site can provide an obligation-free quote for car insurance from the time the transaction takes place. In addition, prospective buyers can compare the specifications and features of as many cars as the buyer wishes, side by side. It is also possible to get a car valuation. These features would make buying a car a very pleasant experience. Furthermore for a modest fee, the car advertisement has the potential to be viewed by an extensive audience not only in the city where the car is located but also by potential buyers around Australia and even globally.

\section{Can this model extend to other industries?}

As already discussed, there are other e-marketspaces conducted by companies such as eBay, Amazon and Alibaba.com but do these businesses use the same revenue model as carsales.com.au?

Amazon charge a margin on their own books sold online around the globe. In contrast, sites such as Biblio.com were created to give local booksellers global reach in assisting readers to find the book they seek. These sites derive revenue from the booksellers placing books for sale (i.e., an advertising fee per book).

eBay and Amazon also receive a transaction fee in addition to selling advertising space on their respective sites. Therefore these sites have two revenue streams.

Realestate.com is another e-marketspace site for the trading of real estate comprising homes, units, townhouses and retirement units. Only authorised real estate agents who subscribe to the site can offer property for sale on the site. An individual who is not a real estate agent cannot offer a property for sale on the website. ${ }^{20}$ Similar to the heavy reliance on car dealers for revenue to carsales.com.au, realestate.com.au relies on the subscriptions paid by agents. In addition to the subscription fee, the site also offers advertising space for a fee. Realestate.com.au also relies on selling advertising space similar to eBay, Amazon and many other websites like YouTube. Paid advertising space on realestate.com.au is open to any corporate entity whether connected or affiliated to real estate or not.

Gumtree.com.au is another marketspace trading site. This site is similar to eBay in that it offers all types of goods and services for a fee. Furthermore revenue is derived from the sale of advertising space on the site. Seek.com.au is another well known and well used site in Australia. Its revenue model is very simple. The site relies on fees placed by an employer seeking an employee. The site has a very good search facility to funnel the results from the multitude of positions available.

These marketspaces mentioned here are among the most popular trading sites and represent some that are dominant within an industry. Even though it is not easy to achieve the scale and complexity of carsales.com.au, the same concept can be applied to many other industries and services as well as directory businesses.

Basically any industry is capable of utilizing the business model of an electronic marketspace facilitating the exchange of goods via the Internet. 


\section{The future of carsales.com.au}

The business choice of online classified trading has been good for carsales.com.au since its product of carrelated information could be wholly handled in the digital/online channel. The site also operates in a sector where there was a large existing market developed by established agents and traditional channels (such as magazines and newspapers).

The online business model appears bright as more of the traditional physical businesses extend their offerings to provide an online presence. That is, the traditional established business is used as the financial support for the online business channel until this channel becomes sustainable. Will there be a tipping point at which point the online business cannibalises the traditional physical store? Only time will tell! The future and sustainability of carsales.com.au would appear assured based on a number of factors.

Firstly carsales.com.au has attained the leading site for the trading of motor vehicles in Australia. It has established itself over many years and has recognized branding. Whilst the site was established primarily for motor vehicles, its success provided the impetus to extend the business to include other affiliated sites (including boatsales.com.au, discountusedcars.com.au, bikesales.com.au, trusksales.com.au, farmmachinerysales.com.au, constructionsales.com.au, plantmachinerysales.com.au, caravancampingsales.com.au, and quicksales.com.au). And the company has worked hard on diversification, expansion and innovation.

Also online businesses have the potential to reach many more potential customers than the traditional advertising methods used many years ago. Traditional advertising was strongly tied to location or 'delivery area.' With globalization, the entire globe is the new delivery area (but at a price). The Australian Government supports e-business and infrastructure for online businesses. Whilst residential users may ultimately pay the major portion for the National Broadband Network, business will benefit from the rollout. So whilst the outlook is positive, carsales.com.au should not become complacent. The business environment is in constant change.

The site itself is an e-marketplace - a website to facilitate the exchange of goods and service by users. However the site does not handle the physical delivery of goods. Perhaps carsales.com.au could provide a car delivery service in situations where the seller and purchaser are geographically located more than say 200km apart. For example a rural purchaser using the carsales.com.au site purchases a motor vehicle from a capital city dealer (or individual). Carsales.com.au could offer the purchaser the convenient option of delivering the motor vehicle to the purchaser for a fee a delivery fee based on distance zones for example \$x for distances between $200 \mathrm{kms}$ and $350 \mathrm{kms}$, and $\$ \mathrm{y}$ for distances between say $350 \mathrm{kms}$ and $500 \mathrm{kms}$. Beyond this zone limit, this option may not be offered.

Carsales.com.au has made the step to move into overseas markets. It has a presence in New Zealand, Malaysia, China and Thailand. As the business model is easy to duplicate, new marketspace companies could commence in foreign countries in competition to carsales.com.au. Carsales.com.au continually has to scan the external environment for potential competitors and take action to maintain its competitive advantage.

Other internet giants and resourceful companies are becoming serious about an online presence and these could be a threat to carsales.com.au's competitive position in the future.

The viability of carsales.com.au's model is based on user loyalty of dealers and individual sellers. Dealers are indirectly being forced into signing up to the carsales.com.au technology or not compete in this emarketspace - a "join them or get left behind" approach. If this loyalty was stolen by a competitor offering cheaper registration and subscription, then carsales.com.au may lose their market leader status. For example if Carsguide, Drive and Trading Post merged, then their combined market share would be $48 \%$ - well in excess of the $38 \%$ enjoyed by carsales.com.au as seen in Table 2.

Other issues for carsales.com.au may be in concerns raised by users of marketspace sites. These concerns include privacy, security, trust, intellectual property, reliability, accuracy, and quality of information. For example, in the terms and conditions of many of these online sites, the sites take the proprietary right to use photos of the items regardless of who physically took the photos. If a professional photographer was contracted to take photos for a dealer, then these photos become the property of the dealer. If the terms of the contract between the photographer and dealer specify that the photo can only be used by the dealer, then the dealer would be precluded from placing this photo of an advertised vehicle on carsales.com.au as doing so would mean that the photo now becomes the property of the site. To overcome this legal ownership of photos conundrum, the advertisements may appear with a 
caption below the photograph reading "This car may be similar to the picture above".

The sustainability of carsales.com.au is governed by the supply and demand of vehicles and other items offered on its associated sites. The site then becomes vulnerable to any economic downturn where many items may be offered but few actually purchased. This may lead to users moving to free sites for example Gumtree.com.au particularly for individual sellers. Furthermore if the economy is in recession mode, then more people may not trade vehicles. That is, they would hold onto their existing vehicle longer until it becomes uneconomical to do so. With lesser turnover, there would be lesser advertisements by dealers which are the main revenue stream of carsales.com.au.

Like all business to be sustainable, they must be vigilant of the changing external environment and become adaptive to changes. Even though carsales.com.au looks good right now, the question is "for how long and on what terms?" Perhaps the outlook for carsales.com.au looks far more promising than the fate of the local motor vehicle manufacturing industry in Australia.

\section{References}

1 Ford, 'About Ford - Australia', (Ford, 2013).

2. Wikipedia, 'Wikipedia: GM Holden: Holden', (Wikipedia, 2013).

3. 1998 Industry Economics Conference, Productivity Commission, Conference Proceedings Canberra, 6--7 July 1998 (Productivity Commission, 1998)

4. Remy Davison, 'Australia's choice: pay for a car industry, or live with the consequences', In: The Conversation, (The Conversation, 2012).

5. Phillip Coorey, Mark Skulley, Michaela Whitbourn and Lucille Keen, 'Ford to pull out of Australian Manufacturing', In: Financial Review, (Financial Review, 2013).

6. Phillip Coorey and Mark Skulley , 'Car industry on brink as SA Premier seeks Abbott's support', In: Financial Review, Financial Review, 2013)

7. M E Porter, 'The Five Competitive Forces That Shape Strategy’, Harvard Business Review, pp24-41.

8. Oneworld, 'An Introduction to oneworld: An alliance of the world's leading airlines working as one', (oneworld, 2013)

9. Qantas, 'Qantas and Emirates', (Qantas, 2013)

10. Michael De La Merced and Bill Vlasco, '\$23bn float puts GM back on the board', In: The Sydney Morning Herald, (Sydney Morning Herald, 2010).

11. Annabel Hepworth, 'Government handouts to auto industry lost in 'black hole", In: The Australian, (The Australian, 2013).

12. Carsales.com.au, 'Annual Report 2012', (carsales, 2013)

13. Magnus Bjornsson, 'The History of eBay', Project for IEF248a, Spring 2001, (cs.brandeis.edu, 2001)

14. History of amazon.com, (btmaushart.iweb.bsu.edu, 2013)

15. Wikipedia, 'Wikipedia: Alibaba group', (alibaba, 2013)

16. ACCC, 'Carsales.com Ltd - proposed acquisition of assets associated with Trading Post from Telstra Corporation Ltd', Statement of Issues, (ACCC, 2012).

17. E. Turban, D. King, J. Lee, T.P. Liang, D. Turban, Electronic Commerce 2012, Pearson Education, London 2012.

18. M. Rappa, Business Models on the Web, Managing the Digital Enterprise, May 16, 2007.

19. L. M. Applegate, e-Business Models: Making Sense of the Internet Business Landscape, Information Technology and the Future Enterprise: New Models for Managers, G W Dickson \& G DeSanctis (eds.) Prentice Hall, 2001.

20. Rea-Group, (rea-group.com, 2013) 